\title{
GENOTOXICITY AND ANTIOXIDANT ENZYME ACTIVITIES INDUCED BY THE CAPTAN FUNGICIDE IN THE ROOT OF BELL PEPPER (Capsicum annuum L. var. grossum L. cv. Kandil)
}

\author{
Müge SEYHAN ${ }^{1}$, Elif YÜZBAŞIOĞLU²*, Eda DALYAN ${ }^{2}$, Ilgın AKPINAR ${ }^{1}$, Muammer ÜNAL ${ }^{2}$ \\ ${ }^{1}$ Institute of Sciences, Istanbul University, Vezneciler, Istanbul, TURKEY \\ ${ }^{2}$ Department of Botany, Faculty of Science, Istanbul University, Beyazit, Istanbul, TURKEY \\ *Corresponding author: ORCID ID: orcid.org/0000-0003-3691-6283, e-mail: aytamka@istanbul.edu.tr
}

Cite this article as:

Seyhan M., Yüzbaşıŏlu E., Dalyan E., Akpınar I., Ünal M. 2019. Genotoxicity and Antioxidant Enzyme Activities Induced by the Captan Fungicide in the Root of Bell Pepper (Capsicum annuum L. var. grossum L. cv. Kandil). Trakya Univ J Nat Sci, 20(2): 97-103, DOI: 10.23902/trkjnat.546647

Received: 29 March 2019, Accepted: 26 July 2019, Online First: 31 July 2019, Published: 15 October 2019

\begin{abstract}
In this study, we investigated the toxic effects of the captan fungicide by using morphological, physiological and cytological parameters in bell pepper (Capsicum annuиm L. var. grossum L. cv. Kandil) root tissue. The seeds of bell pepper were germinated in Petri dishes including different concentrations $(0,25 \mu \mathrm{M}, 50 \mu \mathrm{M}, 100 \mu \mathrm{M}, 150 \mu \mathrm{M})$ of captan fungicide for 7 days. The germination rates and root lengths were significantly reduced in captan-treated seeds. All concentrations caused a significant decrease in mitotic index and increase in different types of chromosomal abnormalities such as c-mitosis and chromosome stickness in meristematic cells of bell pepper root. Captan treatment also induced oxidative stress by leading to membrane damage with an increase in root electrolyte leakage in 7 days-old bell pepper root. Catalase, glutathione reductase and total peroxidase activities increased under different concentrations as a response to oxidative stress. Our results showed that captan fungicide had negative effects on germination and growth in bell pepper seed.
\end{abstract}

Key words: Chromosomal abnormality, antioxidant enzyme activity, pesticide toxicity.

Özet: Bu çalışmada, dolmalık biberde (Capsicum annuum L. var. grossum L. cv. Kandil) kök dokusunda morfolojik, fizyolojik ve sitolojik parametreler kullanarak captan fungisitinin toksik etkisi araştırıldı. Dolmalık biber tohumları 7 gün boyunca farklı konsantrasyonlarda $(0,25 \mu \mathrm{M}, 50 \mu \mathrm{M}, 100 \mu \mathrm{M}, 150 \mu \mathrm{M})$ captan fungisit içeren petri kabında çimlenmiştir. Elde edilen sonuçlar, captanla muamele edilmiş tohumlarda çimlenme oranının ve kök uzunluğunun düştügünü göstermiştir. Ayrıca, captan fungisitinin tüm konsantrasyonları, mitotik indekste önemli bir azalmaya ve biber kökünün meristematik hücrelerinde c-mitoz ve kromozom yapışkanlığı gibi farklı tipte kromozomal anormalliklerin artmasına neden olmuştur. Ayrıca, captan muamelesi, 7 günlük dolmalık biber kökündeki kök elektrolit sızıntısında bir artı̧̧ ile membran hasarına yol açarak oksidatif stresi tetiklemiştir. Oksidatif stres ile başa çıkmak için katalaz, glutatyon redüktaz ve toplam peroksidaz aktivitelerinin dolmalık biber köklerinde farklı captan fungisit konsantrasyonu altında arttığı belirlenmiş̧tir. Elde ettiğimiz sonuçlar captan fungisitinin dolmalık biber tohumundaki çimlenme ve büyümeyi olumsuz yönde etkilediğini göstermiştir.

\section{Introduction}

Pepper (Capsicum annum L.), a member of the Solanaceae family, is cultivated in different parts of the World and is an important vegetable with various fruit types known as bell-shaped, charleston, conic and longgreen all which are consumed either as fresh, processed, pickled or powder (Dağistan et al. 2015). According to the production ratio, pepper is ranked the sixth among commonly grown vegetables in Turkey (Aytop et al. 2014). However, yield and quality of pepper is decreased by many diseases that cause great losses in its production (Abou-Zeid et al. 2016). Many soilborne fungal root rot and wilt pathogens such as Rhizoctonia solani Kühn, Macrophomina phaseolina (Tassi) Goid, Fusarium oxysporum Schlecht. and F. solani (Mart.) Sacc. have been reported to be widespread and attack pepper roots and stems causing severe losses in seed germination, plant growth and yield (Güney \& Güldür 2018).

Fungicides are used to protect agricultural products against fungal infections in seed, root, shoot and leaves of plants. Members of the dicarboximide from the oldest groups of fungicides have been frequently used in these treatments since 1949s (Thomson 1997). Captan is a dicarboximide and phthalimide member non-systemic fungicide. It is one of the most commonly used fungicides in seed treatment and used to protect crops, vegetable and fruit from fungal diseases caused by pathogens such as Phytophthora infestans (Mont.) de Bary and Botrytis cinerea Pers.

Excessive use of pesticides not only poses risk for soil, water and air but also deleteriously affects non-target 
organism including humans, animals and plants (Parween et al. 2016). Many studies showed that indiscriminate use of pesticides results in undesirable consequences one of which is induction of genetic damage on plant cells (Aktar et al. 2009). The most important effect of pesticides is their genotoxic, mutagenic or cytotoxic roles in non-target organism (Çavuşoğlu et al. 2011; Verma \& Srivastava 2018). The alkylating abilities of pesticides break DNA and cause damages in DNA replication (Kaur et al. 2011). Pesticides also lead to mitotic disorders such as abnormal chromosomes, micronucleus formation, chromosomal bridges and polyploidy (Iqbal et al. 2019). Studies revealed that pesticides caused a wide range of genotoxic effects in Allium cepa L. (Türkoğlu 2012, Karaismailoğlu 2017), Vicia faba L. (Singh et al. 2013) Helianthus annuus L. (Karaismailoğlu 2014) and Lycopersicon esculentum Mill. (Akpınar 2014).

Pesticide toxicity can deleteriously affect various metabolic processes by inhibition of germination, retardation of growth, reduction in photosynthesis and alteration of nitrogen/carbon metabolism (Dias 2012). At cellular level, high pesticide concentrations induce oxidative damage which result in accumulation of reactive oxygen species, injury and increase ion leakage of the cell membrane (Parween et al. 2012). Plants are able to develope multiple complex enzymatic antioxidant system including catalase (CAT), peroxidase (POX) and glutathione reductase (GR) to protect themselves against harmful effects of oxidative stress.

In the present study, we investigated the potential genotoxic effect of the captan fungicide on bell pepper Capsicum annuum L. var. grossum L. cv. Kandil by determining mitotic index and chromosomal and mitotic aberrations in root meristems. The toxic effects of captan were also evaluated by considering the alterations in some growth parameters (root length, germination rate and protein content), root electrolyte leakage and antioxidant enzyme activities.

\section{Materials and Methods}

\section{Experimental Design}

The test substance Captan (N-triklorometilmercapto-4siklohekzen-1)(IUPAC Name: $\mathrm{C}_{9} \mathrm{H}_{8} \mathrm{Cl}_{3} \mathrm{NO}_{2} \mathrm{~S}$, CAS No: 133-06-2, molecular weight: $300,59 \mathrm{~g} / \mathrm{mol}$, purity of 99,6\%) was purchased from Pestanal (32054) (Steinheim, Germany) and prepared by ultrapure water. $500 \mu \mathrm{M}$ stock solution was stored in the dark and under $+4^{\circ} \mathrm{C}$. The seeds of Capsicum annиит $(2 \mathrm{n}=24)$ were purchased from a seed company (Agrogen) operating in Tekirdağ, Turkey. All chemicals were obtained from Sigma Aldrich (St. Louis, MO).

The seeds were sterilized in $1 \%$ sodium hypochlorite and imbibed in deionized water for 6 hours. The imbibed seeds were kept on Petri dishes $(9 \mathrm{~cm}$ diameter) containing different concentrations $(25 \mu \mathrm{M}, 50 \mu \mathrm{M}, 100$ $\mu \mathrm{M}, 150 \mu \mathrm{M})$ of captan solutions for 7 days at $25^{\circ} \mathrm{C}$ under dark conditions in an incubator. The seeds of the control group were kept in deionized water.

\section{EC50 Determination}

Bell pepper seeds were primarily treated with different concentrations of captan ranging from $12.5 \mu \mathrm{M}$ to $200 \mu \mathrm{M}$ for EC50 determination. Test concentrations which caused 50\% reduction in root length in comparison with the control group were designated as EC50. EC50 values for captan was $25 \mu \mathrm{M}$ and $150 \mu \mathrm{M}$. After EC50 determination, four different concentrations $(25 \mu \mathrm{M}, 50$ $\mu \mathrm{M}, 100 \mu \mathrm{M}, 150 \mu \mathrm{M})$ were selected for the test applications. In the selection of the experimental concentrations, the doses used by local farmers in agricultural fields were considered.

\section{Germination Rates and Root Growth}

The number of germinating seeds and the root length was determined at the end of the $7^{\text {th }}$ days following applications.

\section{Mitotic Index and Assays}

The root tips were randomly collected from each Petri plate in triplicate for cytological studies. Primary roots were fixed in freshly prepared Carnoy's solution (aceticethanol: $1: 3, \mathrm{v} / \mathrm{v}$ ) in separate vials. Squash preparations were made using $2 \%$ aceto-orcein. For each replicate, about 1000 cells were examined in roots and analyzed with respect to mitosis and chromosomal aberrations. For each treatment, mitotic index was calculated as a percentage by the ratio of dividing cell number to total cell number. Chromosomal abnormalities were counted in prophase, metaphase, anaphase and telophase stages and expressed as a percentage of the total number of abnormalities in the dividing cells.

\section{Electrolyte Leakage}

Electrolyte leakage from fine roots (REL) was determined using the relative conductivity method of Wilner (1955). Roots were washed three times with deionized water to remove surface ions. Each root sample was put into $28 \mathrm{~mL}$ glass bottles containing $16 \mathrm{~mL}$ deionized water of a known conductivity. The sealed bottles were left at room temperature for $24 \mathrm{~h}$ after shaking. The conductivity of the solution in the bottle which was shaken again was measured using a conductivity probe with in-built temperature compensation. After samples were autoclaved at $110^{\circ} \mathrm{C}$ for $10 \mathrm{mins}$, it was cooled to room temperature and the total conductivity was measured for each sample. The 24 $\mathrm{h}$ conductivity was expressed as a percentage $(\%)$.

\section{Analysis of Antioxidant Enzyme Activities}

Root samples were extracted in $0.05 \mathrm{mM}$ potassium phosphate buffer (pH: 7.8) containing $1 \mathrm{mM}$ EDTA and 2\% PVPP (Polyvinylpyrrolidone). The homogenate was centrifuged at $14.000 \times \mathrm{g}$ for $30 \mathrm{~min}$ at $+4^{\circ} \mathrm{C}$, and the obtained supernatant was used in determination of protein and enzyme activity. All spectrophotometric analyses were conducted on Epoch 2 Microplate Spectrophotometer (United States). The soluble protein content was determined by Bradford (1976) method using bovine serum albumin as a standard. Total peroxidase activity was 
assayed by following the increase in absorbance by oxidation of 3,3-diaminobenzidine tetrahydrochloride (DAB) at $465 \mathrm{~nm}$, according to the method of Herzog \& Fahimi (1973). Catalase (CAT, EC 1.11.1.6) activity was analyzed by measuring the rate of decomposition of $\mathrm{H}_{2} \mathrm{O}_{2}$ at $240 \mathrm{~nm}$, as described by Bergmeyer (1970). Glutathione reductase (GR, EC 1.8.1.7) activity was measured by following the change in $340 \mathrm{~nm}$ as oxidised glutathione (GSSG)-dependent oxidation of NADPH, according to the method of Foyer \& Halliwell (1976).

\section{$\underline{\text { Statistical Analysis }}$}

All experimental data were analyzed using the mean \pm standard deviation values of at least 5-10 replicates. The data is suitable for normal distribution according to Shapiro-Wilk test. The significance of differences between the mean values were determined by a one-way ANOVA followed by Tukey Post Hoc Test analysis. All analyzes were performed on GraphPad Prism version 5.2 for Windows (GraphPadSoftware, San Diego, CA).

\section{Results}

The Effect of Captan Fungicide on Seed Germination and Root Growth

The effect of captan fungicide on germination percentage and root length were given in Table 1. 25, 100 and $150 \mu \mathrm{M}$ concentrations caused approximately 32,55 and $66 \%$ reduction in seed germination, respectively. On the other hand, $50 \mu \mathrm{M}$ captan treatment significantly increased germination rate when compared to the control. The root length values significantly decreased by approximately 40, 59, 72 and $74 \%$ with $25,50,100$ and $150 \mu \mathrm{M} / \mathrm{L}$ captan treatments, respectively. $150 \mu \mathrm{M} / \mathrm{L}$ treatment caused the highest inhibition on germination and root length in bell pepper (Table 1).

\section{The Effect of Captan Fungicide on Genotoxicity}

The genotoxic effects of the captan fungicide were evaluated by the mitotic index and the percentage of chromosomal abnormalities in root meristems. The results of the mitotic index $(\%)$ and chromosome abnormality under fungicide treatments were shown in Table 2. Mitotic activity in root meristem cells gradually decreased with increasing captan concentrations. The highest inhibition of mitotic activity (38\%) was observed in $150 \mu \mathrm{M}$ captan treatment. The microscopic investigations revealed that captan treatments induced various chromosomal aberrations in mitosis phase in root meristem cells (Fig. 1). The fungicide treatments reduced cell division frequency in comparison with the control and the maximum inhibition was determined in $150 \mu \mathrm{M}$ treatment. The treatments also significantly affected the anaphase among other phases. The total abnormality frequency increased by 35, 35, 49 and $59 \%$ at $25,50,100$ and $150 \mu \mathrm{M} / \mathrm{L}$ treatments, respectively. The types of chromosome abnormalities were indicated according to sticky chromosome, lagging chromosome, multipolarity, fragment, c-mitosis, chromosome bridge and binucleated (Table 2). When compared to the control, sticky chromosome and multipolarity were commonly observed in dividing cells following captan treatments (Table 2).

\section{The Effect of Captan Fungicide on Membrane Damage}

The root electrolyte leakage (REL) increased significantly, when compared to the control, by 37, 57, 94, 105 and $111,08 \%$ in 25, 50, 100 and $150 \mu \mathrm{M}$ captan treatments, respectively (Fig. 2).

\section{The Effect of Captan Fungicide on Antioxidant Enzyme Activities}

Captan fungicide negatively affected protein content in bell pepper root tissues. The increasing treatment concentrations decreased protein content (Fig. 3) and the reduction was significant for 100 and $150 \mu \mathrm{M} / \mathrm{L}$ treatments. We investigated POX, CAT and GR activities in roots treated with different fungicide concentrations (Fig. 4). POX activity increased by 26, 29, 68 and $80 \%$ at $25,50,100$ and $150 \mu \mathrm{M} / \mathrm{L}$ treatments, respectively. CAT and GR activities significantly increased with only 150 $\mu \mathrm{M} / \mathrm{L}$ treatment by 17 and $32 \%$, respectively (Fig. 4).

Table 1. The effect of different concentrations of captan fungicide on germination rate $(\%)$ and root length $(\mathrm{cm})$ in bell pepper. Data are means $( \pm)$ standard deviations $(\mathrm{SD}) .\left(^{*}\right)$ represent adjusted $\mathrm{p}$ values $(\mathrm{p}<0.0001)$ for statistically significant differences from the control as revealed by one-way ANOVA analysis followed by Tukey Multiple Comparison Test.

\begin{tabular}{ccc}
\hline \hline Treatment & Germination $(\boldsymbol{\%})$ & Root Length $(\mathbf{c m})$ \\
\hline \hline Control & $15.66 \pm 0.54$ & $1.62 \pm 0.34$ \\
$\mathbf{2 5} \boldsymbol{\mu M} / \mathbf{L}$ & $10.63{ }^{*} \pm 0.55$ & $0.9 *^{*} \pm 0.28$ \\
$\mathbf{5 0} \boldsymbol{\mu M} / \mathbf{L}$ & $58.1 * \pm 0.47$ & $0.67 * 0.11$ \\
$\mathbf{1 0 0} \boldsymbol{\mu M} / \mathbf{L}$ & $7.1 *^{*} \pm 0.51$ & $0.46^{*} \pm 0.13$ \\
$\mathbf{1 5 0} \boldsymbol{\mu M} / \mathbf{L}$ & $5.3 *^{*} \pm 0.49$ & $0.42 * \pm 0.12$ \\
\hline \hline
\end{tabular}

Table 2. Mitotic index and the frequency of chromosome abnormalities in the root meristematic cells in bell pepper treated with different concentrations of captan $(\mathrm{S}=\mathrm{Sticky}$ chromosome; L=Lagging chromosome; $\mathrm{M}=$ Multipolarity; $\mathrm{F}=$ Fragment; $\mathrm{C}=\mathrm{C}$-mitosis; $\mathrm{B}=$ Bridge; $\mathrm{BN}=$ Binucleated). Data are means $( \pm$ ) standard deviations $(\mathrm{SD}) .(*)$ represent adjusted $\mathrm{p}$ values $(\mathrm{p}<0.0001)$ for statistically significant differences from the control by one-way ANOVA analysis followed by Tukey Multiple Comparison Test.

\begin{tabular}{ccccccccccc}
\hline \hline \multirow{2}{*}{ Concentration } & MI (\%) & \multirow{2}{*}{$\begin{array}{c}\text { Dividing } \\
\text { Cell }\end{array}$} & S & L & M & F & C & B & BN & $\begin{array}{c}\text { Total Abnormality } \\
\text { Frequency (\%) }\end{array}$ \\
\hline \hline Control & $12.55 \pm 0.74$ & 127 & 2 & - & - & - & - & - & - & $1.64 \pm 1.17$ \\
$25 \mu \mathrm{M}$ & $9.6^{*} \pm 1.09$ & 107 & 20 & - & 9 & 1 & 4 & - & 3 & $34.58^{*} \pm 2.21$ \\
$50 \mu \mathrm{M}$ & $9.53^{*} \pm 1.62$ & 102 & 14 & 6 & 12 & 1 & - & 2 & 1 & $35.29^{*} \pm 3.12$ \\
$100 \mu \mathrm{M}$ & $7.82^{*} \pm 0.97$ & 81 & 19 & 2 & 5 & 2 & 3 & 1 & 8 & $49.38^{*} \pm 2.42$ \\
$150 \mu \mathrm{M}$ & $7.73^{*} \pm 1.99$ & 78 & 21 & 3 & 11 & 1 & 5 & - & 5 & $58.97^{*} \pm 3.53$ \\
\hline \hline
\end{tabular}



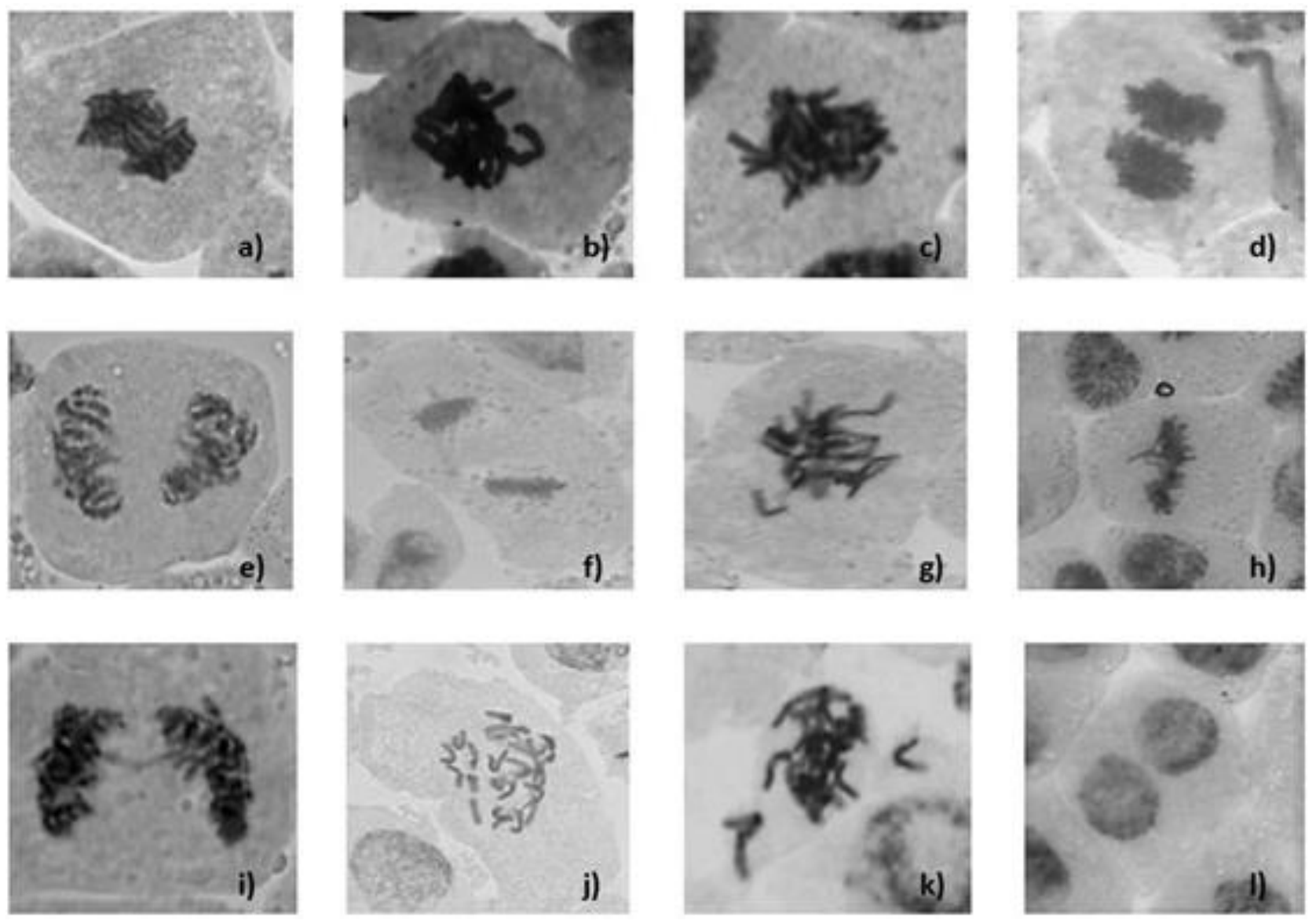

Fig. 1. Some chromosomal abnormalities which were seen in the root meristem cells in bell pepper following captan treatments of different concentrations. a-d) Stickiness; e-f) Multipolarity; g-h) Lagging Chromosomes; i) Bridge; j) C-mitosis; k) Fragmentation; 1) Binucleated cell.

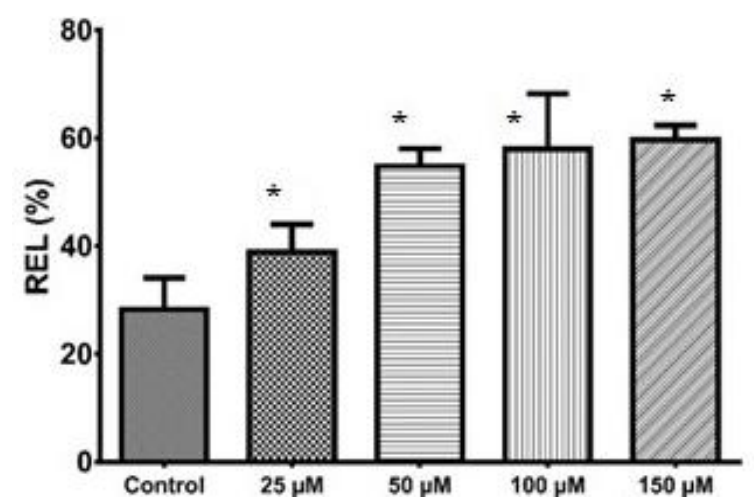

Fig. 2. The effects of different concentrations of captan fungicide on REL (\%). Bars represent standard deviations (SD). $(*)$ represent adjusted $\mathrm{p}$ values $(\mathrm{p}<0.0001)$ for statistically significant differences from the control as revealed by one-way ANOVA analysis followed by Tukey Multiple Comparison Test.

\section{Discussion}

Random, excessive and unconscious use of pesticides have recently been an important pollutant for the environment (Parween et al. 2016). The soil is the first compartment affected by the pesticide toxicity, which in turn leads plant root sytems to be directly or indirectly influenced from pesticide related pollution. Thus, it is important to understand effects of pesticides on root

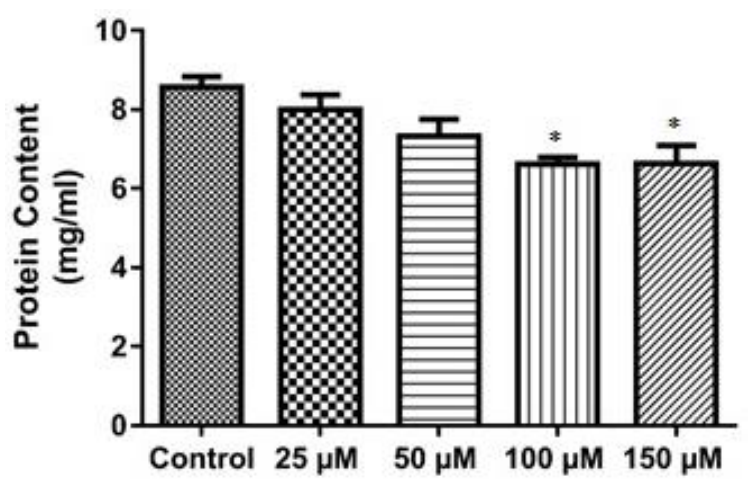

Fig. 3. The effects of different concentrations of captan fungicide on soluble protein content in bell pepper root. Bars represent standard deviations (SD). (*) represent adjusted $\mathrm{p}$ values $(p<0.0001)$ for statistically significant differences from the control as revealed by one-way ANOVA analysis followed by Tukey Multiple Comparison Test.

systems in plant development. In the first step, pesticide toxicity causes an inhibition on seed germination and reduction on growth and development. In this study, we showed that the captan fungicide negatively influenced seed germination and root growth in bell pepper. This finding revealed that the fungicide had a toxic effect for bell pepper germination and root growth when used at concentrations from 25 to $150 \mu \mathrm{M}$. The reduction in 

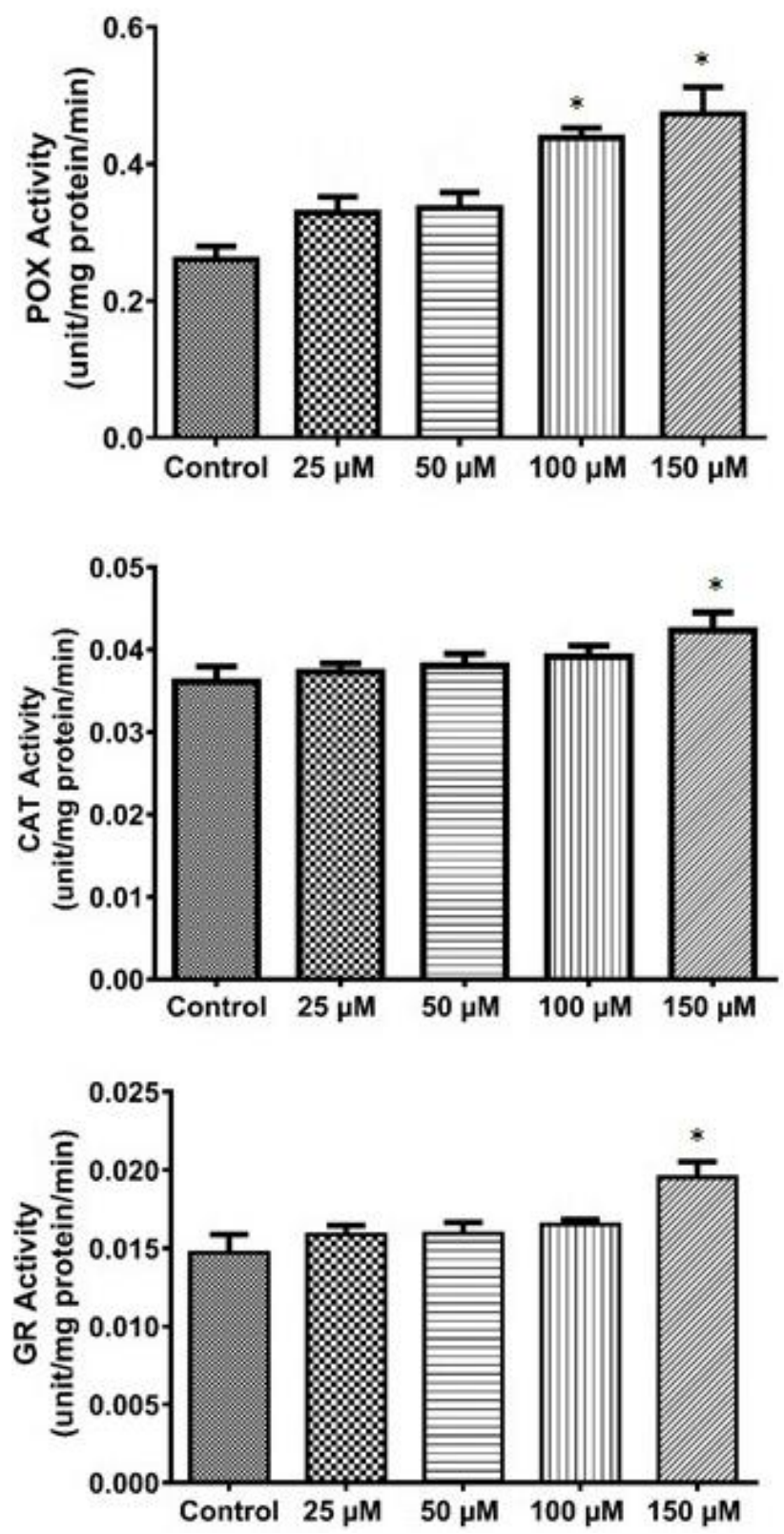

Fig. 4. The effects of different concentrations of captan fungicide on POX, CAT and GR activities in bell pepper root. Bars represent standard deviations (SD). (*) represent adjusted $\mathrm{p}$ values for statistically significant differences from the control as determined by one-way analysis of ANOVA followed by Tukey Multiple Comparison Test. POX activity $(*)$ : $p<0.001$, CAT activity $(*): \mathrm{p}<0.01$, GR activity $(*): \mathrm{p}<0.006$.

germination may be explained by inhibition of important enzymes like amylase and protease, inhibition of imbibition of water and inhibition of mobilization of sugar (Gange et al. 1992). You \& Barker (1997) showed that root fresh weight of tomato plants were decreased by $47 \%$ after 6 days of glufosinate herbicide treatment. Karaismailoğlu \& İnceer (2017) determined that the insecticide deltamethrin decreased root growth in sunflowers (Helianthus annuus). Another study revealed that increasing concentration of tricyclazole and thiabendazole fungicides caused inhibition of germination in the tropical crop plant Trigonella foenum - graecum $\mathrm{L}$ (Mahapatra et al. 2019).

Mitotic index is commonly known as an indicator for determination of cytogenetic damage under stressful conditions. In this study, different concentration $(25,50$, 100 and $150 \mu \mathrm{M}$ ) of captan fungicide significantly reduced the mitotic index in the root meristem of bell pepper as compared to their controls (Table 2). Pesticides may cause to inactivation of the cell cycle specific proteins and inhibition of DNA synthesis enzymes such as DNA polymerase and hindering in the G2-phase of the cell cycle, preventing the cell from entering mitosis (Mahapatra et al. 2019). Singh et al. (2013) determined that mitotic index and induction of chromosomal abnormalities increased under application of different concentration of alphamethrin and endosulfan insecticides in the meristematic cells of $V$. faba roots. Gill \& Shaukat (2000) observed that mitotic index reduced by application of 5, 10, 20 and 40 ppm captan fungicide in meristematic cells of A. cepa.

Agrochemical toxicity directly leads to genotoxicity in many plant species. In recent studies, $A$. cepa and $V$. faba have commonly been used for indicating the genotoxic effect of pesticide usage. These studies showed a decrease in mitotic index and an increase in chromosomal abnormalities (Bonciu et al. 2018). The structural changes in the chromosomes are explained by alteration in the organization of histone and other proteins. These negative effect of protein organization cause changes on structure and adhesiveness of nuclear chromatin (Kurás 2004). Besides, stickiness can be formed by reaction of pesticides with DNA or proteins (Aksoy \& Deveci 2012). Our result indicated that the captan fungicide had a harmful effect on chromosome structure by enhancement of sticky and multipolarity in meristematic cells of bell pepper root. The stickiness of chromosomes may cause incomplete separation of sister chromosomes as a result of cross-linkage chromoproteins (Aksoy \& Deveci 2012). Gill \& Shaukat (2000) indicated that captan fungicide led to chromosomal aberrations including chromosome stickiness, anaphasic bridges, and distribution of prophase in A. cepa cells. Aksoy \& Deveci (2012) reported that Pomarsol Forte WP 80 fungicide triggered an increase of chromosomal abnormalities in soybean (Glycine max L.).

Excessive use of pesticides has triggered the induction of oxidative stress due to the production of reactive oxygen species (ROS) in many plant species (Yüzbaşığlu \& Dalyan 2019). ROS accumulation damage cell membrane structure via changing the composition of the lipid bilayer and its result in leakage of potassium so electrolyte leakage is associated with membrane damage and potassium efflux in the cells (Demidchik et al. 2014). The present study revealed that different concentrations of captan induced oxidative stress by enhanced REL in bell pepper root. Similarly, different concentrations of monocrotophos insecticide causedan increase in electrolyte leakage in Azolla microphylla Kaulfuss (Raja et al. 2012). 
Plants can response to oxidative stress via induction of antioxidant enzyme systems including POX, CAT and GR. These enzymes play a role for scavenging of the member of highly toxic ROS such as $\mathrm{H}_{2} \mathrm{O}_{2}$ and superoxide radical (Yüzbaşığlu et al. 2017). Our result showed that CAT, POX and GR were induced in $150 \mu \mathrm{M} / \mathrm{L}$ captantreated root of bell pepper. In addition, all concentrations of captan enhanced the activity of POX enzyme in bell pepper root. POX enzyme is highly sensitive to pesticide application in plants because it plays a role in response to pesticides by detoxifying the pesticides and eliminating $\mathrm{H}_{2} \mathrm{O}_{2}$ in plants (Yüzbaşığlu \& Dalyan 2019). Our previous study determined that thiram fungicide treatment caused oxidative stress. Further, it increased the antioxidant enzyme activities including CAT, POX and GR in tomato seedlings (Yüzbaşığlu \& Dalyan 2019). Another study has indicated that mancozeb and chlorpyrifos increased CAT and POD activities in A. cepa seedling in a time and concentration-dependent manner (Fatma et al. 2018).

\section{References}

1. Abou-Zeid, N.M., Mahmoud, N.A. \& Rania, A.S. 2016. Effect of some Biotic and Abiotic Applications on Control of Fusarium Wilt of Pepper Plants. Egyptian Journal of Phytopathology, 44 (2):103-118.

2. Akpınar, I. 2014. The Physiological Effects of Thiram on Tomato (Lycopersicum esculentum Miller) Plants. Istanbul University Graduate School of Science and Engineering Biology Master Thesis.

3. Aksoy, O. \& Deveci, A. 2012. The investigation of the cytotoxic effects of some pesticides on soybean (Glycine $\max$ L.) Cytologia, 77: 475-483.

4. Aktar, M.W., Sengupta D. \& Chowdhury, A. 2009. Impact of pesticides use in agriculture: their benefits and hazards. Interdisciplinary Toxicology, 2:1-12.

5. Aytop, Y., Cukadar, M. \& Sahin, A. 2014. Agricultural Sector Profile of Turkey in the World. Turkish Journal of Agricaltural and Natural Sciences, 1: 688-694.

6. Bergmeyer, N. 1970. Methoden der enzymatischen, Analyse. Akademie Verlag, Berlin, Vol. 1. pp 636-647.

7. Bonciu, E., Firbas, P., Fontanetti, C.S., Wusheng, J., Karaismailoğlu, M.C., Liu, D., Menicucci, F., Pesnya, D.S., Popescu, A., Romanovsky, A.V., Schiff, S., Ślusarczyk, J., de Souza, C.P., Srivastava, A., Sutan, A. \& Papini A. 2018. An evaluation for the standardization of the Allium cepa test as cytotoxicity and genotoxicity assay. Caryologia, 71(3): 191-209.

8. Bradford, M.M. 1976. A rapid and sensitive method for the quantitation of microgram quantities of protein utilizing the principle of protein-dye binding. Analytical Biochemistry, 72: $248-254$.

9. Çavuşoğlu, K., Yalçın, E., Türkmen, Z., Yapar, K., Çavuşoğlu, K. \& Çiçek, F., 2011. Investigation of Toxic Effects of the Glyphosate on Allium cepa. Journal of Agricultural Sciences, 17: 131-142.

10. Dağistan, E., Demirtas, B., Tapki, N., Üremis I. \& Arslan, M. 2015. Economic analyses of pesticide usage on red

\section{Conclusion}

Despite the fact that use of a wide range of fungicides have risen productivity of crops, fungicides have also harmful effects on plant growth and development. As revealed by our results, the captan fungicide caused genotoxic effects in meristematic cells of bell pepper. Also, its toxicity has affected the membrane permeability and antioxidant enzyme activities in bell pepper root. These findings can contribute to increasing knowledge about the side effects of pesticides and it may help to develop a new perspective to minimize the destructive effects of pesticides in plant growth, development, and yield.

\section{Acknowledgement}

This study was supported by the Scientific Research Projects Coordination Unit of Istanbul University (Project numbers: 41885) and the Scientific and Technological Research Council of Turkey (TÜBITAK), Grant No: $114 Z 016$.

peppers (Capsicum) in Hatay Province in Turkey and determination of production cost. Custos e@gronegócio on line, 11(3): 56-65.

11. Demidchik, V., Straltsova, D., Medvedev, S. S., Pozhvanov, G. A., Sokolik, A. \& Yurin, V. 2014. Stressinduced electrolyte leakage: the role of $\mathrm{K}+$ permeable channels and involvement in promed cell death and metabolic adjustment. Journal of Experimental Botany, 65 (5): 1259-1270.

12. Dias, M.C. 2012. Phytotoxicity: an overview of the physiological responses of plants exposed to fungicides. $\begin{array}{lll}\text { Journal of } & \text { Botany, }\end{array}$ https://doi.org/10.1155/2012/135479.

13. Gange, A.C., Brown, V.K. \& Farmer, L.M. 1992. Effects of pesticides on the germination of weed seeds: implications for manipulative experiments. Journal of Applied Ecology, 29: 303-310.

14. Gill, R.S.A. \& Shaukat, S.S. 2000. Genotoxic effects of Dithane M-45 fungicide on root meristems of Allium cepa L. in vitro. Pakistan Journal of Biological sciences, 3(1): 114-117.

15. Güney, İ.G. \& Güldür, M.E. 2018. Inoculation Techniques for Assessing Pathogenicity of Rhizoctonia solani, Macrophomina phaseolina, Fusarium oxysporum and Fusarium solani on Pepper Seedlings. Turkish Journal of Agricultural Research, 5(1): 1-8.

16. Fatma, F., Verma, S., Kamal, A. \& Srivastava, A. 2018. Phytotoxicity of pesticides mancozeb and chlorpyrifos: correlation with the antioxidative defence system in Allium cepa. Physiology and Molecular Biology of Plants, 24(1): 115-123.

17. Foyer, C.H. \& Halliwell, B. 1976. The presence of glutathione and glutathione reductase in chloroplast: a proposed role in ascorbic acid metabolism. Planta, 133: 2125.

18. Herzog, V. \& Fahimi H. 1973. Determination of the activity of peroxidase. Analytical Biochemistry, 55: 554-562. 
19. Iqbal, M., Abbas, M., Nisar, J., Nazir, A. \& Qamar, A. Z. 2019. Bioassays based on higher plants as excellent dosimeters for ecotoxicity monitoring: A review. Chemistry International, 5(1): 1-80.

20. Karaismailoğlu, M.C. 2014. Evaluation of potential genotoxic effect of trifluralin in Helianthus annuus L. (sunflower). Caryologia, 67(3): 216-221.

21. Karaismailoğlu, M.C. 2017. Assessments on the potential genotoxic effects of fipronil insecticide on Allium cepa somatic cells. Caryologia, 70(4): 378-384.

22. Karaismailoğlu, M.C. \& İnceer, H. 2017. Evaluation of potential genotoxic and cytotoxic effects of deltamethrin insecticide on somatic chromosomes of Helianthus annuus L. Caryologia, 70(4): 295-301.

23. Kaur, R., Kaur, S. \& Lata, M. 2011. Evaluation of DNA damage in agricultural workers exposed to pesticides using single cell gel electrophoresis (comet) assay. Indian Journal of Human Genetic, 17(3): 179-187.

24. Kurás, L. 2004. Characterization of protein-DNA association in vivo by chromatin immunoprecipitation. In. Dickson RC, Mendenhall MD, editors. Signal transduction protocols, methods in molecular biology (Vol. 284). Totowa: Humana Press Inc.; p. 147-162.

25. Mahapatra, K., De, S., Banerjee, S. \& Roy, S. 2019. Pesticide mediated oxidative stress induces genotoxicity and disrupts chromatin structure in fenugreek (Trigonella foenum - graecum L.) seedlings. Journal of Hazardous Materials, 369: 362-374.

26. Parween, T., Mahmooduzzafar, S., Jan \& Fatma, T. 2012. Evaluation of oxidative stress in Vigna radiata L. in response to chlorpyrifos. International Journal of Environmental Science and Technology, 9: 605-612.

27. Parween, T., Jan, S., Mahmooduzzafar, S., Fatma, T. \& Siddiqui, Z.H. 2016. Selective Effect of Pesticides on Plant-A Review. Critical Reviews in Food Science and Nutrition, 56(1): 160-179.

28. Raja, W., Rathaur, P., John, S.A., Ramteke, P.W. \& Dar, R.A. 2012. Effect of monocrotophos on electrolytic leakage, proline content and nitrogen metabolism of floating Pteridophyte Azolla microphylla. The Holistic Approach to Environment, 2(3): 111-120.

29. Singh, A., Srivastava, A.K. \& Singh, A.K. 2013. Exogenous application of salicylic acid to alleviate the toxic effects of insecticides in Vicia faba L. Environental Toxicology, 28: 666-672.

30. Thomson, D. 1997. Confusion Amongst Codling Moth Fellows Continues: A Commercial Perspective On The İmplementation Of Codling Moth Mating Disruption in North America. International Organisation for Biological Control, 20(1): 57-63.

31. Türkoğlu, S. 2012. Determination of genotoxic effects of chlorfenvinphos and fenbuconazole in Allium cepa root cells by mitotic activity, chromosome aberration, DNA content, and comet assay. Pesticide Biochemisty and Physiology, 103(3): 224-230.

32. Wilner, J. 1955. Results Of Laboratory Tests For Winter Hardiness Of Woody Plants by Electrolyte Methods. Proceedings of the American Society for Horticultural Science, 66: 93-99.

33. Verma, S. \& Srivastava, A. 2018. Cyto-genotoxic consequences of carbendazim treatment monitored by cytogenetical analysis using Allium root tip bioassay. Environmental Monitoring and Assessment, 190(4): 238.

34. You, W. \& Barker, A.V. 1997. Herbicidal actions of rootapplied glufosinate ammonium on tomato plants. Journal of Amercian Society for Horticultural Science, 127(2): 200204.

35. Yüzbaşıŏlu, E. \& Dalyan, E. 2019. Salicylic acid alleviates thiram toxicity by modulating antioxidant enzyme capacity and pesticide detoxification systems in the tomato (Solanum lycopersicum Mill.). Plant Physiology and Biochemistry, 135: 322-330.

36. Yüzbaşıŏlu, E., Dalyan, E., Akpinar, I. 2017. Changes in photosynthetic pigments, anthocyanin content and antioxidant enzyme activities of maize (Zea mays L.) seedlings under high temperature stress conditions. Trakya University Journal of Natural Sciences, 18(2): 97-104. 